\title{
Morphoanatomy of the stem in Cyperaceae
}

\author{
Ana Claudia Rodrigues ${ }^{1,3}$ and Maria Emília Maranhão Estelita ${ }^{2}$
}

Received: September 23, 2008. Accepted: March 20, 2009

RESUMO - (Morfoanatomia do caule de algumas Cyperaceae). As espécies da família Cyperaceae são normalmente perenes com caule subterrâneo principalmente do tipo rizomas, entretanto outros tipos também podem ocorrer, como cormos e tubérculos. Foram examinados os caules subterrâneos de cinco espécies de Cyperaceae. Cyperus rotundus e Fuirena umbellata tem rizoma plagiotrópico, enquanto que C. esculentus, C. odoratus, Hypolytrum schraderianum e Bulbostylis paradoxa tem rizoma ortotrópico. Em C. rotundus e C. esculentus ocorrem cormos e em C. esculentus ocorrem estolões. O corpo primário é originado a partir da atividade do meristema apical e em níveis subseqüentes, a partir do meristema de espessamento primário (MEP). O crescimento secundário é resultado da atividade do meristema de espessamento secundário (MES), e ocorre nos rizomas de H. schraderianum, B. paradoxa, C. odotarus e F. umbellate. O procâmbio e o MEP originam feixes vasculares colaterais em $H$. schraderianum e feixes anfivasais nas demais espécies. O MES origina um sistema vascular com floema e xilema associados. De acordo com os resultados, o conceito do tipo caulinar em Cyperaceae depende da morfologia externa, função, período de vida, atividade dos meristemas de espessamentos e da quantidade relativa de parênquima.

Palavras-chave: bulbo, cormo, estolão, meristema de espessamento primário, meristema de espessamento secundário, rizoma

ABSTRACT - (Morphoanatomy of the stem in Cyperaceae). Cyperaceae are usually perennial, with underground stems mainly rhizomatous, however, other stem types may also occur, such as corms and tubers. The underground stems of five Cyperaceae species were examined. Cyperus rotundus and Fuirena umbellata have plagiotropic rhizomes, while C. esculentus, C. odoratus, Hypolytrum schraderianum and Bulbostylis paradoxa have orthotropic rhizomes. Corms occur in C. rotundus and C. esculentus, and stolons in C. esculentus. The primary body originates from the activity of the apical meristem and later, from the primary thickening meristem (PTM). Secondary growth results from secondary thickening meristem (STM) activity, and occurs in rhizomes of $H$. schraderianum, B. paradoxa, C. odotarus and F. umbellata. The procambium and the PTM give rise to collateral bundles in H. schraderianum, and amphivasal bundles in the remaining species. The STM gives rise to the vascular system with the associated phloem and xylem. According to our results, the concept of stem type in Cyperaceae depends on external morphology, function, life phase, activity of the thickening meristems and the relative amount of parenchyma.

Key words: bulb, corm, primary thickening meristem, rhizome, secondary thickening meristem, stolon

\section{Introduction}

Cyperaceae are well represented in Brazil, with around 600 species (Luceño \& Alves 1997), distributed in different environments such as the Cerrado (Atlantic forest), Caatinga (swamp) and coastal environments. They are generally perennial plants, with considerable variation in vegetative morphology (Bell 1991) with stems that are mostly underground. According to Metcalfe (1971), Cyperaceae are rhizomatous, with horizontal, branched rhizomes, straight aerial scapes, bracts and terminal inflorescences. Other stem types may also occur, such as corms and tubers in Cyperus rotundus and C. esculentus, respectively (Wills \& Briscoe 1970, Gifford \& Bayer 1995). Bell \& Tomlinson (1980) emphasise the term "rhizomatous" due to the architectural diversity of these stems within the family; they may occur in the form of an elongated axis without thickening, with a thickened axis, with reduced internodes and sympodial growth (Rodrigues \& Estelita 2002) or monopodial growth.

Preliminary studies on stem anatomy in Cyperaceae, such as the paper by Metcalfe (1971), showed only a few general characteristics of the organ; Eiten (1969), Wills \& Briscoe (1970), Bendixen (1973), Wills et al. (1980), Menezes et al. (2005) and Prata et al. (2007) also addressed some aspects of the anatomy of the adult organs. Few studies exist on stem ontogenesis in this group, but among those that do exist, two are highlighted: Gifford \& Bayer (1995) analyzed the underground system of C. esculentus and Rodrigues \& Estelita (2002) described the rhizomes of $C$. giganteus in the developmental stage.

In monocotyledons the stems can present two thickening meristems: the primary thickening meristem (PTM) and the secondary thickening meristem (STM) (Rudall 1991). PTM, together with the apical meristem, has the function of forming the primary body by means of a gradual increase in thickness (DeMason 1979a; b). The occurrence of PTM, although it has several denominations, has been described for many monocotyledons (Cheadle 1937; Krauss 1948; DeMason 1979a; b; 1980; 1983; Stevenson \& Fisher 1980; DeMason \& Wilson 1984; Rudall 1991; Gifford \& Bayer 1995; Rodrigues \& Estelita 2002; 2007; Menezes et al. 2005; Martins \& Appezzato-da-Glória 2006). STM is responsible for secondary growth (DeMason 1984), occurring mainly in arborescent monocotyledons of the Superorder Lilifloreae, mainly in Asparagales and Liliales (Tomlinson \& Zimmermann 1969; Rudall 1991). However, according to Rudall (1984; 1991; 1995) some herbaceous Lilifloreae also present STM, particularly those which are closely related to the shrubby and arborescent groups of Iridaceae, such as Patersonia and Witsenia among others. In Cyperaceae, Rodrigues \& Estelita (2002) observed the presence of STM in the rhizome of Cyperus giganteus.

According to Diggle \& DeMason (1983a; b) PTM and STM are subsequent phases of activity of the same meristem; also, Rodrigues \& Estelita (2002) comment that

\footnotetext{
1 Universidade Federal de Santa Catarina, Centro de Ciências Biológicas, Departamento de Botânica, Florianópolis, SC, Brasil

2 Universidade de São Paulo, Instituto de Biociências, Departamento de Botânica, São Paulo, SP, Brasil

3 Corresponding author: anclaro@uol.com.br
} 
STM is the result of the activity change of PTM. In groups where both are present they can be continuous (Diggle \& DeMason 1983a; b; DeMason \& Wilson 1984; Rudall 1995; Rodrigues \& Estelita 2002) at least in one phase of the life cycle (Stevenson \& Fisher 1980).

Cheadle (1937) considers the association between the habit of the plants and secondary growth to be an important factor for determining the phylogenesis of monocotyledons. According to the author, it is possible that secondary growth is a primitive character, which may be relevant when associated with other characteristics. Corroborating this view, Tomlinson \& Zimmermann (1969) relate the amount of secondary tissue with stem habit in several kinds of monocotyledons.

Although some authors have described the stem morphoanatomy of Cyperaceae species, many of these works do not focus on the origin and activity of the tissues and also present misunderstanding of organ denominations and concepts. The aim of this work is to present data on rhizome, stolon and corm organogenesis, seeking to give more accurate definitions and use the presence and activity of thickening meristems, as well as the relative amount of parenchyma, as support for the characterization of stem types.

\section{Material and methods}

The underground stems of Cyperus rotundus L., C. esculentus L., C. odoratus L., Fuirena umbellata Rottb., Hypolytrum schraderianum Ness. and Bulbostylis paradoxa Ness were analyzed.

Cyperus rotundus, C. esculentus, $C$. odoratus and Fuirena umbellata were collected from the garden of the Botany Department, Bioscience Institute, University of São Paulo. Hypolytrum schraderianum was collected from the Juréia-Itatins Ecological Reserve, in Iguape municipality, São Paulo/SP and Bulbostylis paradoxa came from Serra do Cipó/MG.

From each species were collected 10 specimens (A.C. Rodrigues et al. 29, 30, 31, 86, 87 and 88 respectively). Fragments of the underground system were fixed in FAA 70 (Johansen 1940) and stored in alcohol $70 \%$, with glycerin drops in the more delicate structures.

In order to study organogenesis, a series of sections were made from the stem tips at different stages of development. The samples were dehydrated in tertiary butanol series (Johansen 1940), infiltrated in butanol acetate, paraffin oil and pure paraffin before finally being set in paraffin. The material was sectioned in a Reichert - Jung 2040 microtome with a steel razor, the thickness varied from 8 to $15 \mu \mathrm{m}$, the sections were stained with safranin and astra blue (Bukatsch 1972) or safranin and "fast green" and assembled in Canadian balsam.

Cytochemistry tests were carried out on hand-cut sections of the fixed material. Lugol solution was used to identify starch (Jensen 1962), ferric chloride to test the phenolic substances, Sudam IV for the lipophilic substances (Jensen 1962), and phloroglucin acid for lignin (Johansen 1940). The documentation was carried out using an Olympus Vanox photomicroscope.

Samples of adult rhizome fragments were macerated using a solution of hydrogen peroxide and acetic acid, according to Franklin (1945).

In the analysis of tracheal elements, the macerated material was dehydrated in diethyl series up to alcohol $100 \%$. For complete dehydration hexametildesylasane (HMDS) (Bozzola \& Russel 1991) was used, replacing the critical point of $\mathrm{CO}_{2}$. Afterwards, the samples were spread on an aluminum stand using double sided adhesive carbon tape, covered with gold in a Baltec metallizer, model SCD 005, and analyzed in an MEV Philips, model XL30.

\section{Results}

Cyperus rotundus presents an underground stem system formed by corms and rhizomes (Fig. 1A). The corm is formed by a contracted, juicy axis surrounded by reddish brown cataphylls. The rhizome (Fig. 1A) is slender and plagiotropic, with internodes and cataphylls similar to the previous ones, but smaller in size.

The underground system of Cyperus esculentus is formed by corms, rhizomes and stolons (Fig. 1B). The corm is similar to that of $C$. rotundus. The stolon is slender and plagiotropic, with elongated internodes delimited by small cataphylls, and forms a corm at its extremity. After the formation of this final corm the stolon degenerates. The rhizome is similar to that of $C$. rotundus. In the apical region, it develops a sprouting zone with contracted internodes (Fig. 1B).

The rhizomes of Fuirena umbellata, Cyperus odoratus, and Hypolytrum schraderianum are sympodial and thick (Fig. 1C-1F), with reduced internodes and cataphylls; in the cataphyll axil, the lateral buds appear (Fig. 1C-D) forming new branches. Every growth phase constitutes a sympodial or propagulum unit. In $F$. umbellata the sympodial units form a plagiotropic rhizome (Fig. 1C) and in the remaining species each unit is vertical (Fig. 1D-E). In H. schraderianum the sympodial units have a slender basal region known as the "neck" (Fig. 1E-F, arrows), which is fragile and can be easily broken. The rhizome of Bulbostylis paradoxa (Fig. $1 \mathrm{G})$ is monopodial and the union of the central axis with lateral branches promotes diameter enlargement (Fig. 4E).

The vegetative stem tip is congested and the apical meristem is surrounded by the leaf primordial (Fig. 2A-D), like in Cyperus esculentus, C. rotundus, C. odoratus, Fuirena umbellata and Hypolytrum schraderianum. In the promeristem, the organisation tunica-corpus is clearly distinguished, with the tunica having two to two layers of cells (Fig. 2B-C). From the apical meristem, the protoderm, the fundamental meristem and the procambium strands are differentiated (Fig. 2A-D).

Figure 2D shows the intercalary meristems at the base of several internodes of $F$. umbellata. It changes into rib form, i.e., the cells are arranged in vertical columns through transverse divisions (Fig. 2E). Near the tip is the primary thickening meristem (PTM) (Fig. 2A-B, D), which is common to all species observed. The PTM (Fig. 2A-B, D) is formed by several layers of cells arranged in radial rows and located in the peripheral apical region of the stem. Its cells have thin walls and considerable vacuolation, which makes the tissue easier to observe at a smaller microscopic amplification.

In all the stems analyzed, the protoderm originates a uniseriate epidermis and the fundamental meristem originates a parenchyma with amyloplasts and a considerable number of idioblasts with phenolic substances; the region next to the epidermis will form the hypoderm. The procambium originates collateral vascular bundles in $H$. schraderianum and amphivasal in the remaining species. 

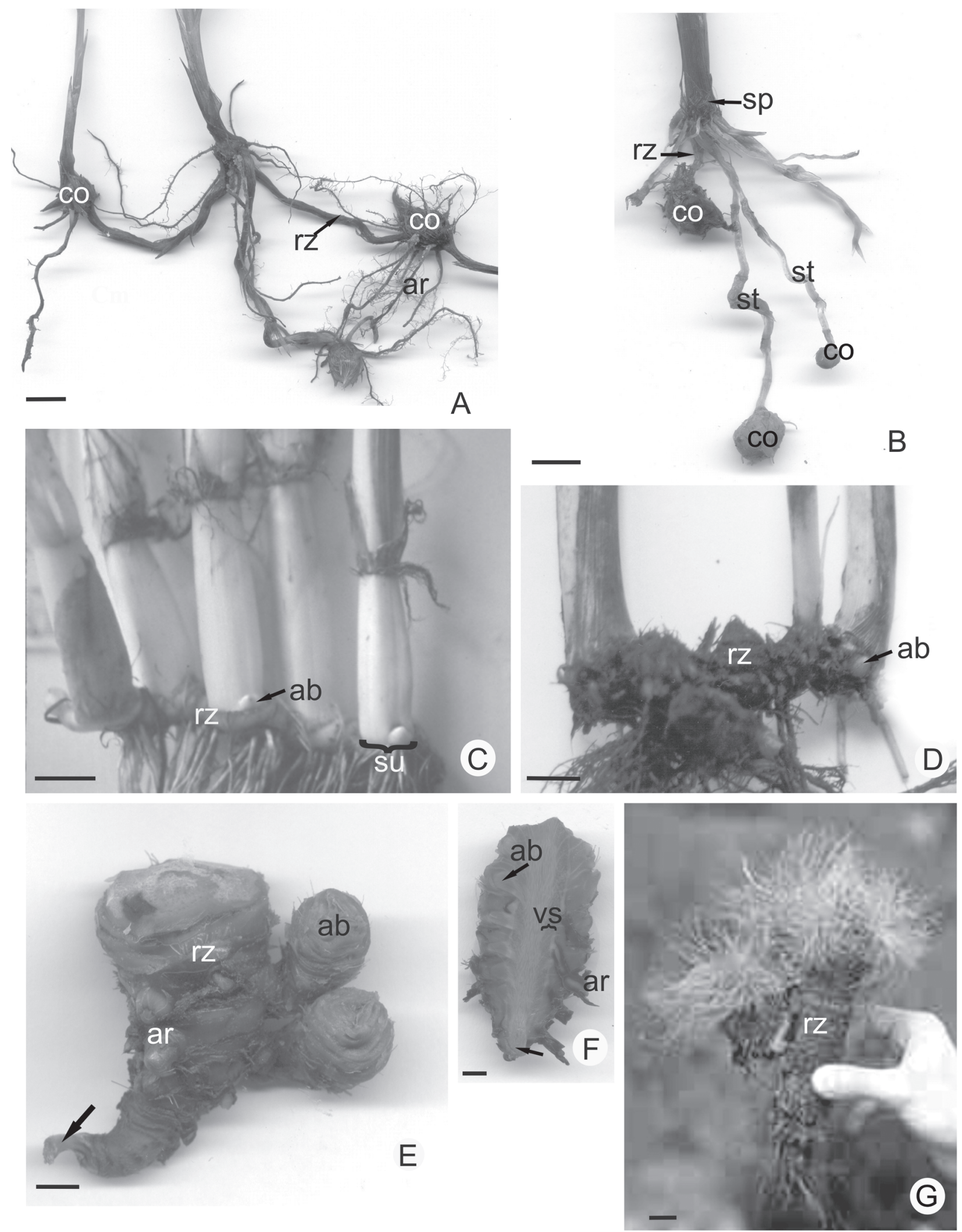

Figure 1. Underground stems of Cyperaceae species. A. Cyperus rotundus L. B. C. esculentus L. C. Fuirena umbellata Rottb. D. C. odoratus L. E-F. Hypolytrum schraderianum Ness. F. Longitudinal section of the rhizome. Arrows indicate "neck" region. G. Bulbostylis paradoxa Ness. st, stolons; co, corm; ab, axillary bud; ar, adventitious root; rz, rhizome; vs, secondary vascular system; su, sympodial unit; sp, sprouting zone. Scale bars: A-B = $10 \mathrm{~cm} ; \mathrm{C}-\mathrm{F}=1 \mathrm{~cm} ; \mathrm{G}=1.5 \mathrm{~cm}$. 
In cross section near the apical meristem of all the analyzed stems, the PTM is arranged in a circle around the procambium bundles (Fig. 3A-B); from its installation the vascular cylinder is defined (Fig. 3C-F). The PTM produces parenchyma to the outside (which originates the internal cortex) and collateral vascular bundles to the inside in Hypolytrum schraderianum (Fig. 4D) and amphivasal vascular bundles in the other species (Fig. 4A-C).
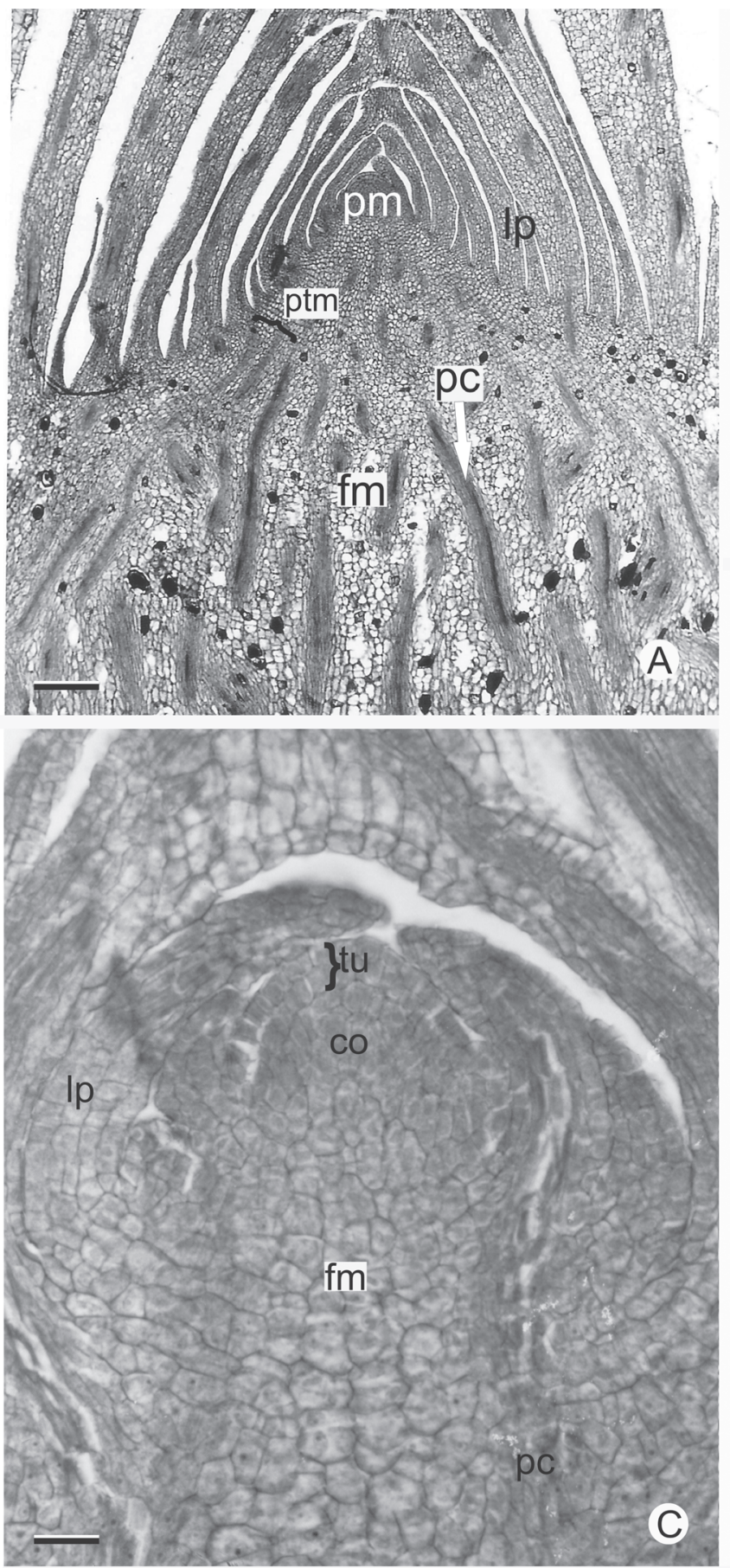

From the tip, in the basipetal direction, an increase in stem diameter is observed which is mainly the result of PTM activity when forming a large part of the inner cortex (Fig. 2A, C). The PTM also produces adventitious roots (Fig. 3D-E) and is continuous with the PTM of the axillary bud (Fig. 3C, arrow).

The rhizome of Bulbostylis paradoxa is considerably branched and its branches remain attached to the main axis,
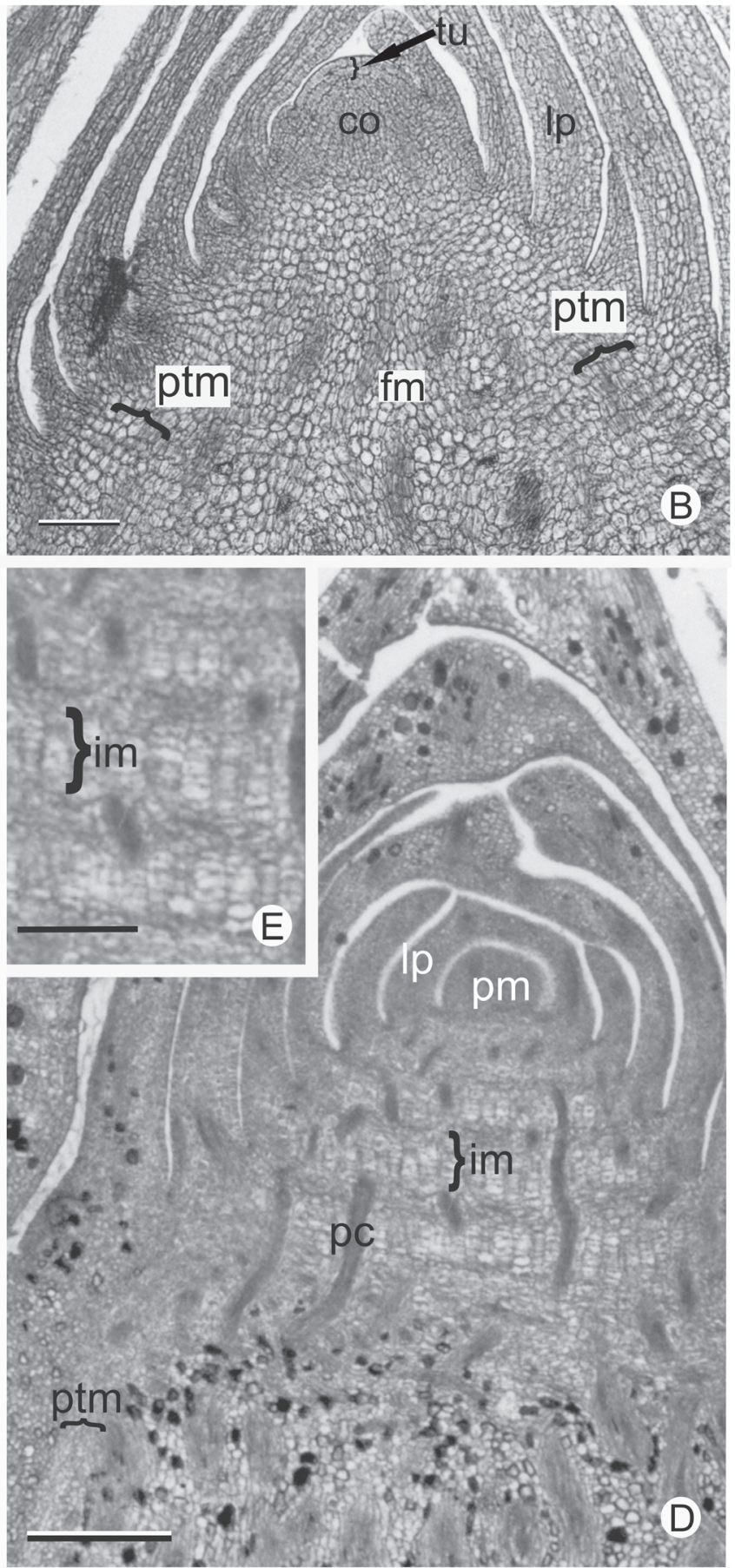

Figure 2. Longitudinal sections of the rhizome vegetative apex in Cyperaceae species. A-B. Hypolytrum schraderianum Ness. C. Cyperus rotundus L. D-E. Fuirena umbellata Rottb. co, corpus; pc, procambium; fm, fundamental meristem; ptm, primary thickening meristem; im, intercalary meristem; pd, protoderm; fp, leaf primordium; pm, promeristem; tu = tunica. Scale bars: $\mathrm{A}=200 \mu \mathrm{m} ; \mathrm{B}=100 \mu \mathrm{m} ; \mathrm{C}=40 \mu \mathrm{m} ; \mathrm{D}=220 \mu \mathrm{m} ; \mathrm{E}=110 \mu \mathrm{m}$. 
which enables it to be observed in cross section. The PTM also surrounds the group of procambium bundles of each branch (Fig. 4E, 3A). In this species the PTM only has activity in its interior, producing vascular bundles.

In the rhizomes of Cyperus rotundus and C. esculentus, as well as in the stolons and corms of $C$. esculentus, the
PTM only has activity on the outside, producing considerable amounts of parenchyma (Fig. 4F, 5A-B). Therefore, the vascular bundles are originated only from the procambium. However, in the sprouting zone of C. esculentus (Fig. 4A), as well as in the corm of C. rotundus the PTM also has activity to the inside (Fig. 3B).
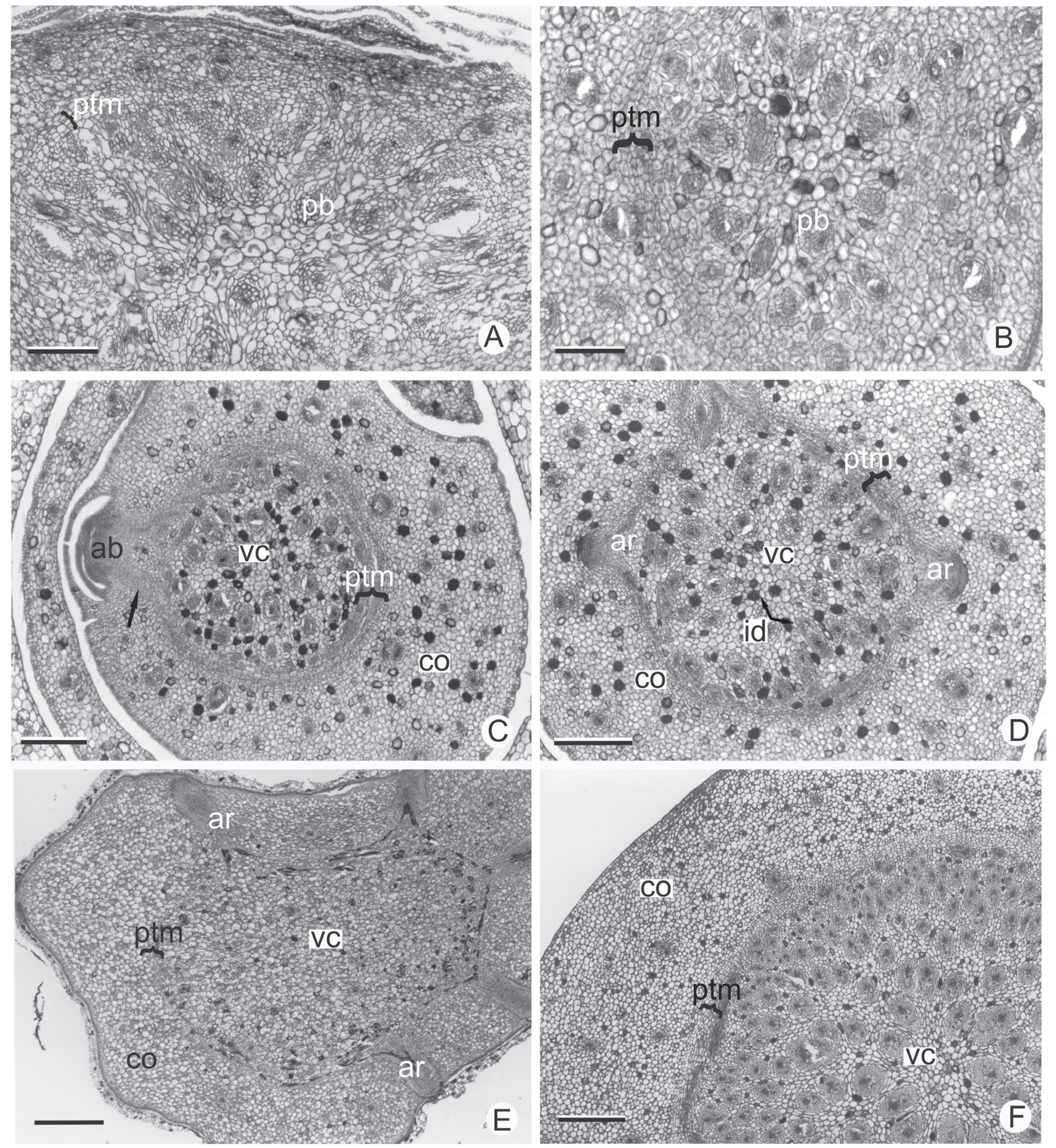

Figure 3. Transverse sections of the stem in development in Cyperaceae species. A-B. Section near the apical meristem where it is possible to see PTM arranged in a circle around the procambium bundles. A. Rhizome of Bulbostylis paradoxa Ness. B. Corm of Cyperus rotundus L. C-F. Sections where PTM can be observed between the cortex and the vascular cylinder. C-D. Corm of C. rotundus L. C. The continuity of ptm in the stem is observed with ptm in the axillary bud (arrow). D. The ptm also produces adventitious roots. E. Corm of C. esculentus L. F. Rhizome of Hypolytrum schraderianum Ness. co, cortex; pb, procambium bundles; vc, vascular cylinder; ab, axillary bud; id, idioblast; ptm, primary thickening meristem; ar, adventitious root. Scale bars: A, C-D = $160 \mu \mathrm{m}$; B = $140 \mu \mathrm{m} ; \mathrm{E}-\mathrm{F}=400 \mu \mathrm{m}$. 
In general, the external activity of the PTM gradually decreases until differentiation of the endodermis and pericycle occurs (Fig. 5C). In subsequent levels, in the rhizomes of Hypolytrum schraderianum, Fuirena umbellata, Cyperus odoratus and Bulbostylis paradoxa the pericycle (now the remains of PTM) changes activity and produces interspersed phloem and xylem, not organized in vascular bundles (Fig. 6A-D). This change of activity transforms the pericycle into the secondary thickening meristem (STM) in which the products are situated externally to the primary vascular bundles (Fig. 6E-F), i.e. those originating from the procambium and the PTM. A special situation occurs in Hypolytrum schraderianum, in which secondary growth does not occur in the "neck" region (Fig. 7A-B).
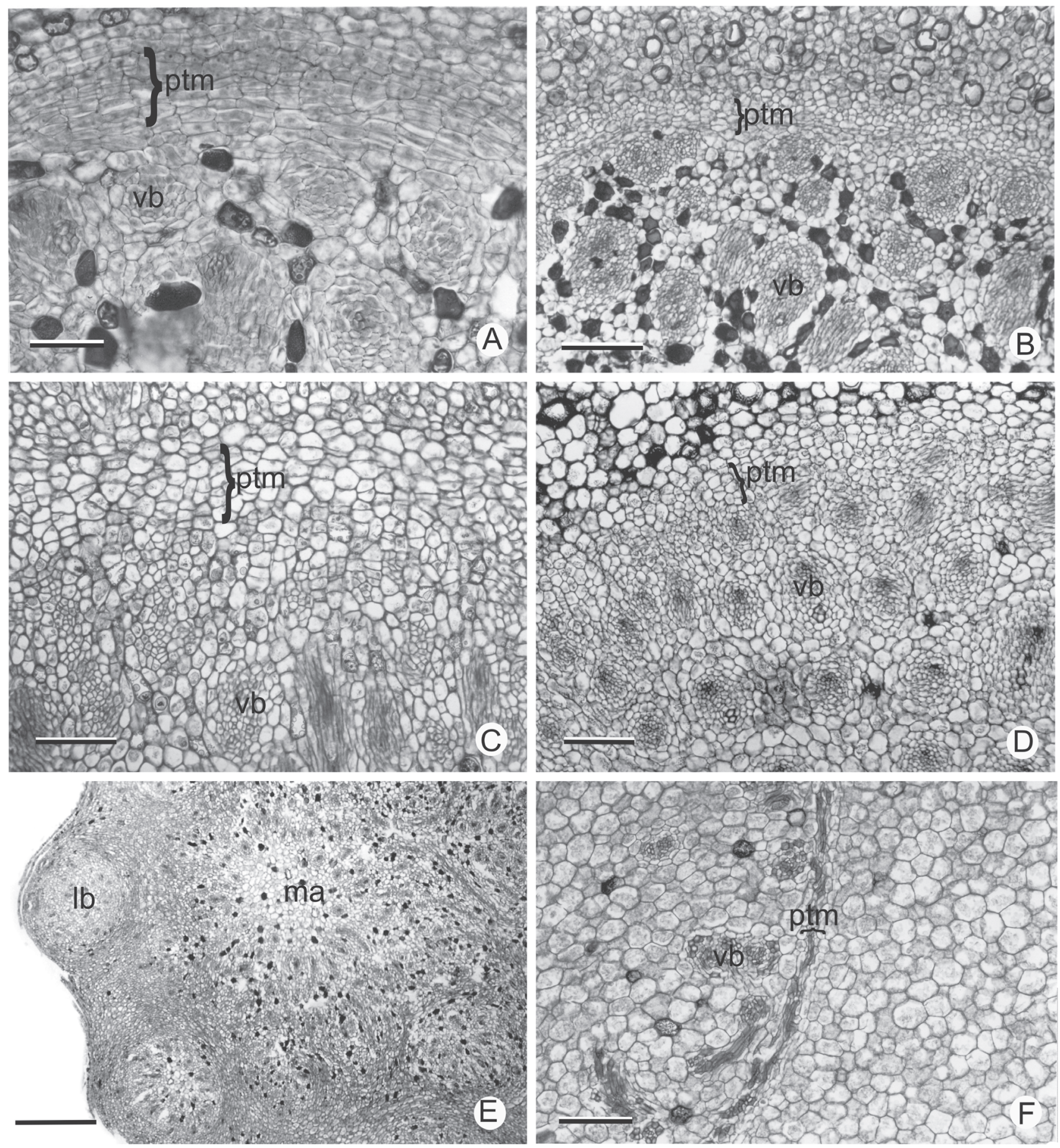

Figure 4. Transverse sections of the stem in development in Cyperaceae species. A-D. Sections showing ptm activity. The ptm forms parenchyma to the outside (which originates the internal cortex) and vascular bundles to the inside. A. Cyperus esculentus L. B. C. odoratus L. C. Bulbostylis paradoxa Ness. D. Hypolytrum schraderianum Ness. E. B. paradoxa Ness where the branches remain attached to the main axis. F. C. esculentus $\mathrm{L}$. The ptm forming parenchyma to the outside can be observed. ptm, primary thickening meristem; vb, vascular bundles; ma, main axis; lb, lateral branches. Scale bars: $\mathrm{A}=40 \mu \mathrm{m} ; \mathrm{B}-\mathrm{E}=80 \mu \mathrm{m} ; \mathrm{F}=400 \mu \mathrm{m}$. 
When mature, the endodermis cells show lignin in Hypolytrum schraderianum, Bulbostylis paradoxa, Fuirena umbellata and Cyperus odoratus (Fig. 7C-D). During primary growth the cortical region (Fig. 3C-F) is formed by an amilaceous parenchyma, with thin walls and a few intercellular spaces, and may present idioblasts with phenolic compounds (Fig. 3C-D). In H. schraderianum, a higher concentration of idioblasts is observed in the "neck" region. The cortex, in its mature phase, is distinguished by external cortex or hypoderm (originating from the fundamental meristem) and
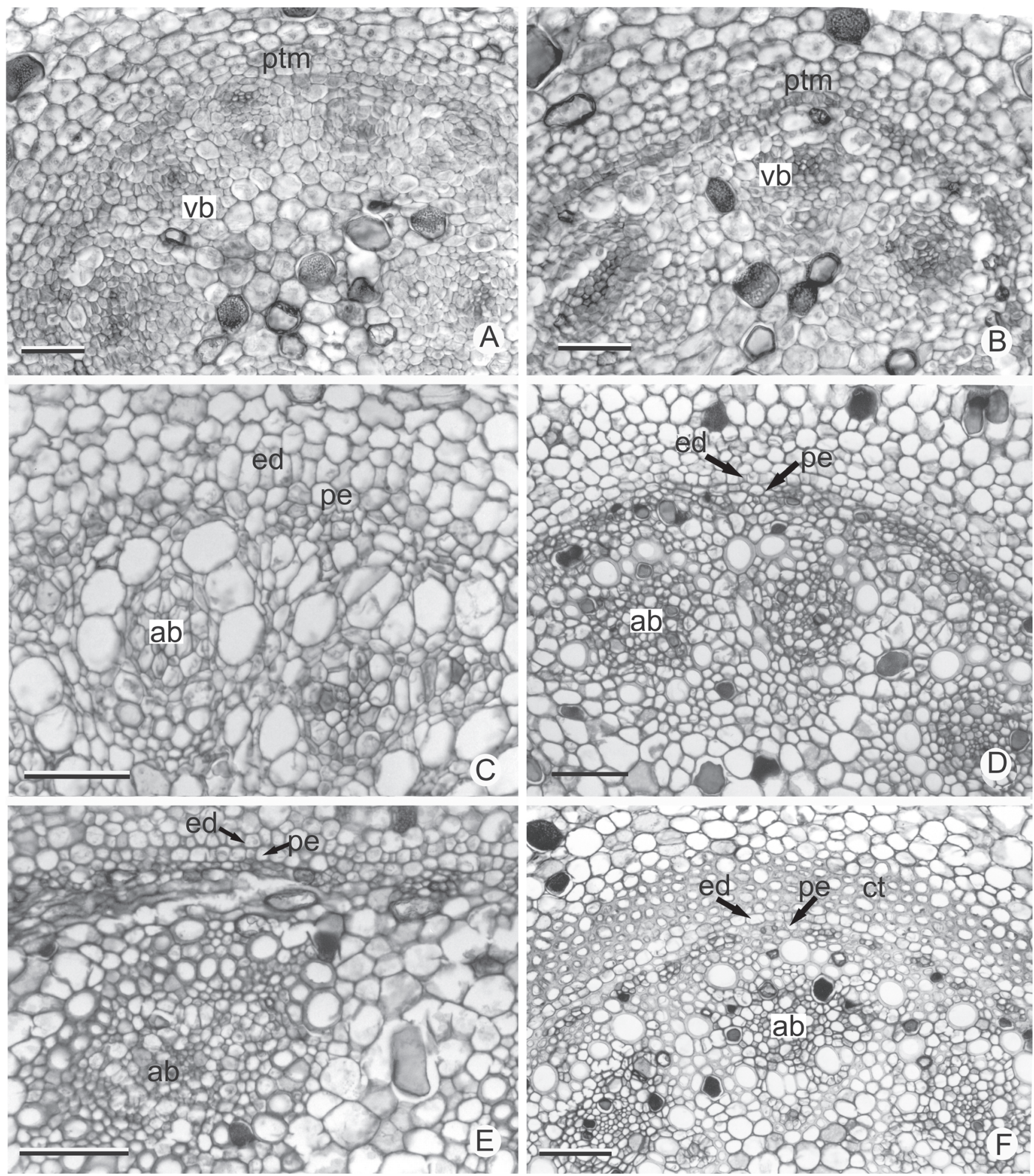

Figure 5. Transverse sections of the stem in development in Cyperaceae species. A-B. Rhizome of Cyperus rotundus L. The ptm activity forming parenchyma to the outside is observed. C-D. Endodermis and pericycle in differentiation. C. Stolons of C. esculentus L. D-F. Cyperus rotundus L. D. Rhizome. E. Corm. F. Rhizome. The internal cortical cells thickened can be observed. ct, cortical cells thickened; ed, endodermis; ab, amphivasal vascular bundle; vb, vascular bundle; ptm, primary thickening meristem; pe, pericycle. Scale bars: A-B $=40 \mu \mathrm{m} ; \mathrm{C}=45 \mu \mathrm{m} ; \mathrm{D}-\mathrm{F}=80 \mu \mathrm{m}$ 

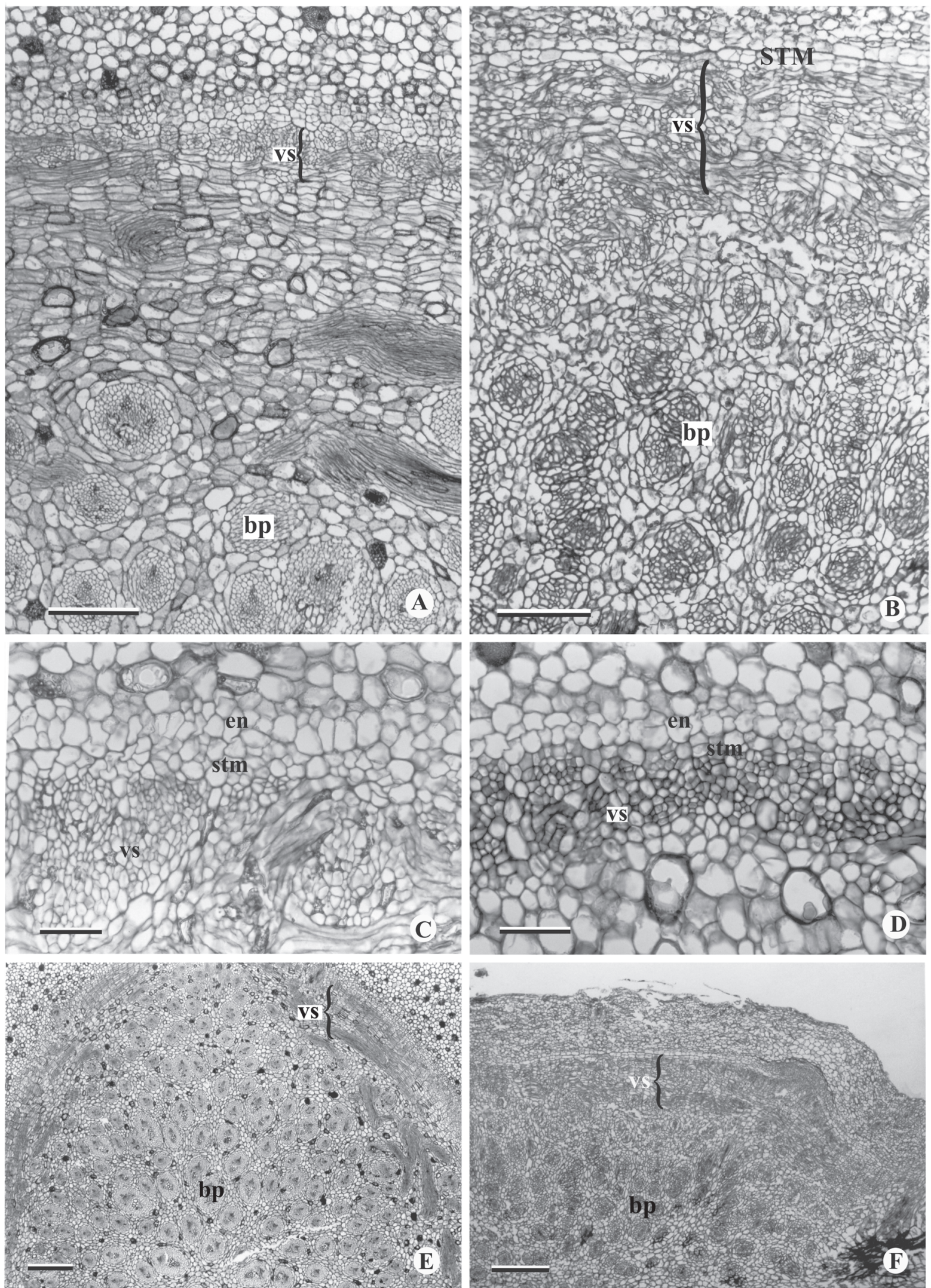

Figure 6. Transverse sections of the stem in development in Cyperaceae species showing STM activity. A. Hypolytrum schraderianum Ness. B-C. Bulbostylis paradoxa Ness. D. Cyperus odoratus L. E-F. Sections showing the vascular cylinder where the outlying location of the secondary vascular system can be observed. E. H. schraderianum Ness. F. B. paradoxa Ness. en, endodermis; bp, vascular bundle primary; vs, secondary vascular system. Scale bars: A $=135 \mu$ m; $\mathrm{B}=155 \mu \mathrm{m} ; \mathrm{C}-\mathrm{D}=40 \mu \mathrm{m} ; \mathrm{E}-\mathrm{F}=350 \mu \mathrm{m}$. 
internal cortex (originating from the PTM). In the hypoderm, the cells are elongated and the amount of idioblasts with phenolic compounds is relatively small in relation to the internal cortex. In $C$. rotundus, F. umbellata and $H$. schraderianum, the internal cortical cells may also be thickened (Fig. 5F, 7D). In the rhizome and stolon of C. esculentus and rhizome of $C$. rotundus, the internal cortex forms the aerenchyma by division and cell lysis.

The tracheal elements originating from the procambium and the PTM are represented by elements of elongated vessels with or without appendices (Fig. 8A-B). The vessel elements of the secondary growth are relatively shorter than those from the primary growth and present branches (Fig. 8C-D). Unlike the other species, Hypolytrum schraderianum presents only tracheids in the secondary growth stage (Fig. 8E-F).

\section{Discussion}

According to Metcalfe (1971) the rhizome is the main underground stem of Cyperaceae. However, there is considerable disagreement as to its definition (Bell \& Tomlinson 1980; Font Quer 1982; Haines \& Lye 1983; Bell 1991), which leads several authors to define other stem types, such as stolon, corm and tuber, as rhizome (Wills \& Briscoe 1970; Bendixen 1973; Wills 1987; Gifford \& Bayer 1995). In the present study, stem classification is based not only on morphology but also on function and life phase. Therefore, rhizome is understood as being a perennial organ, normally underground, orthotropic or plagiotropic, monopodial or sympodial, with nodes delimited by cataphylls; it may have a storage function (when thickened) as well as a vegetative
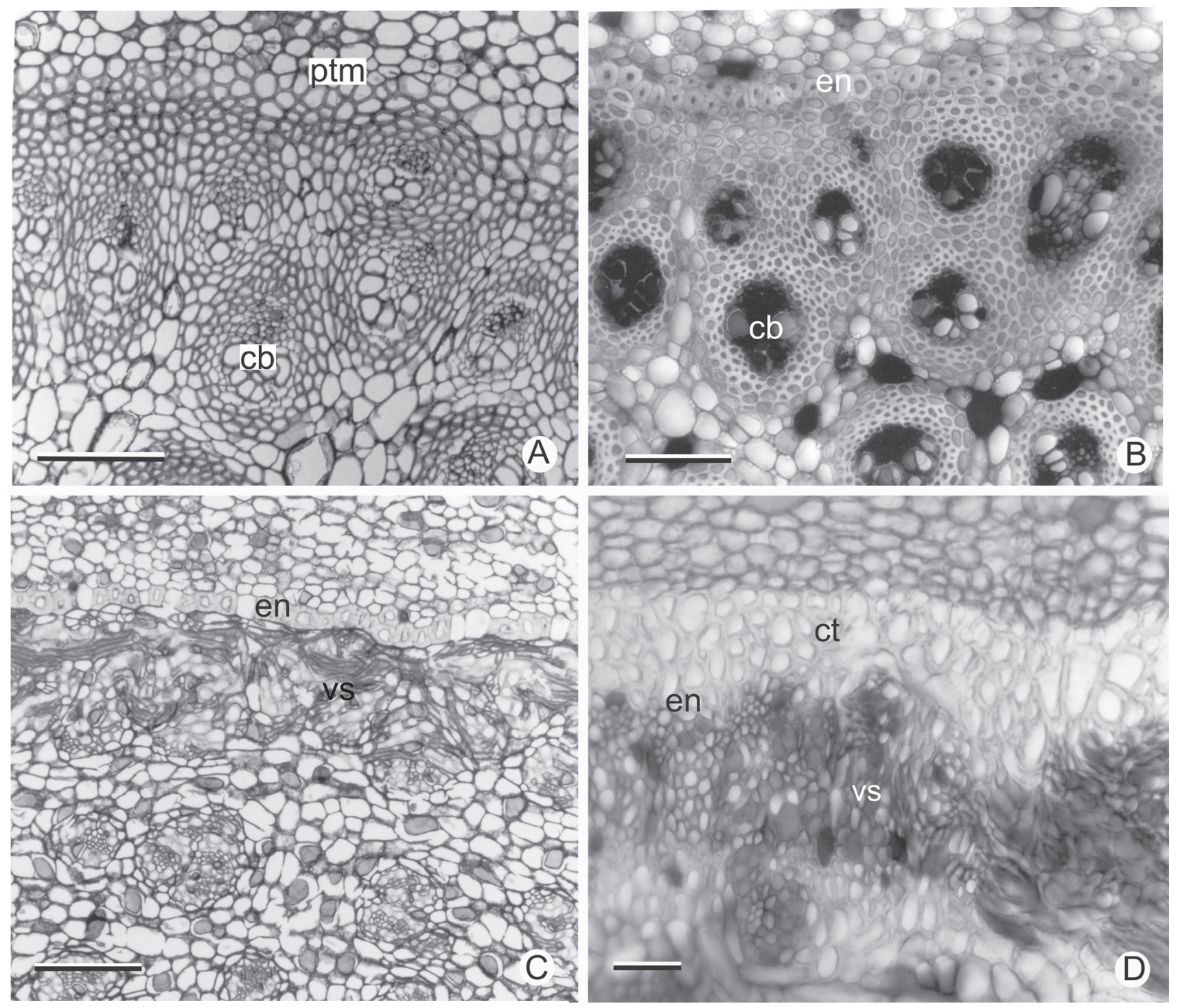

Figure 7. Transverse sections of the stem in Cyperaceae species. A-B. The "neck" region from Hypolytrum schraderianum Ness rhizome with only primary growth. C. Rhizome of Bulbostylis paradoxa Ness showing thickening endodermis. D. Hypolytrum schraderianum Ness. rhizome showing the endodermis and internal cortical cells thickened. ct, cortical cells thickened; $\mathrm{ptm}=$ primary thickening meristem; en $=$ endodermis; $\mathrm{cb}=$ collateral vascular bundle; vs $=$ secondary vascular system. Scale bars: A-B $=80 \mu \mathrm{m} ; \mathrm{C}=140 \mu \mathrm{m} ; \mathrm{D}=100 \mu \mathrm{m}$. 
reproduction function. Thickened rhizomes occur in Cyperus odoraus, Fuirena umbellata, Hypolytrum schraderianum and Bulbostylis paradoxa. Cyperus rotundus and C. esculentus have tender, slender rhizomes.

According to Haines \& Lye (1983) the distinction on between slender rhizomes and stolons is not always clear; the stolons can grow and give rise to a new plant or, first, give rise to a corm or bulb. So, Holm (1929) reported that stolons always emerge from an axillary bud. These are delicate, tender, underground, plagiotropic stems; after the formation of a new organ at the extremity, they degenerate, leaving a new organ which is independent of the mother plant. This mechanism makes the vegetative reproduction process much more efficient when compared to the others. Then, stolons are ephemeral organs, as Estelita-Teixeira (1982) reported for Oxalis. Rhizomes are not ephemeral and do not degenerate. This information is true in the present paper.
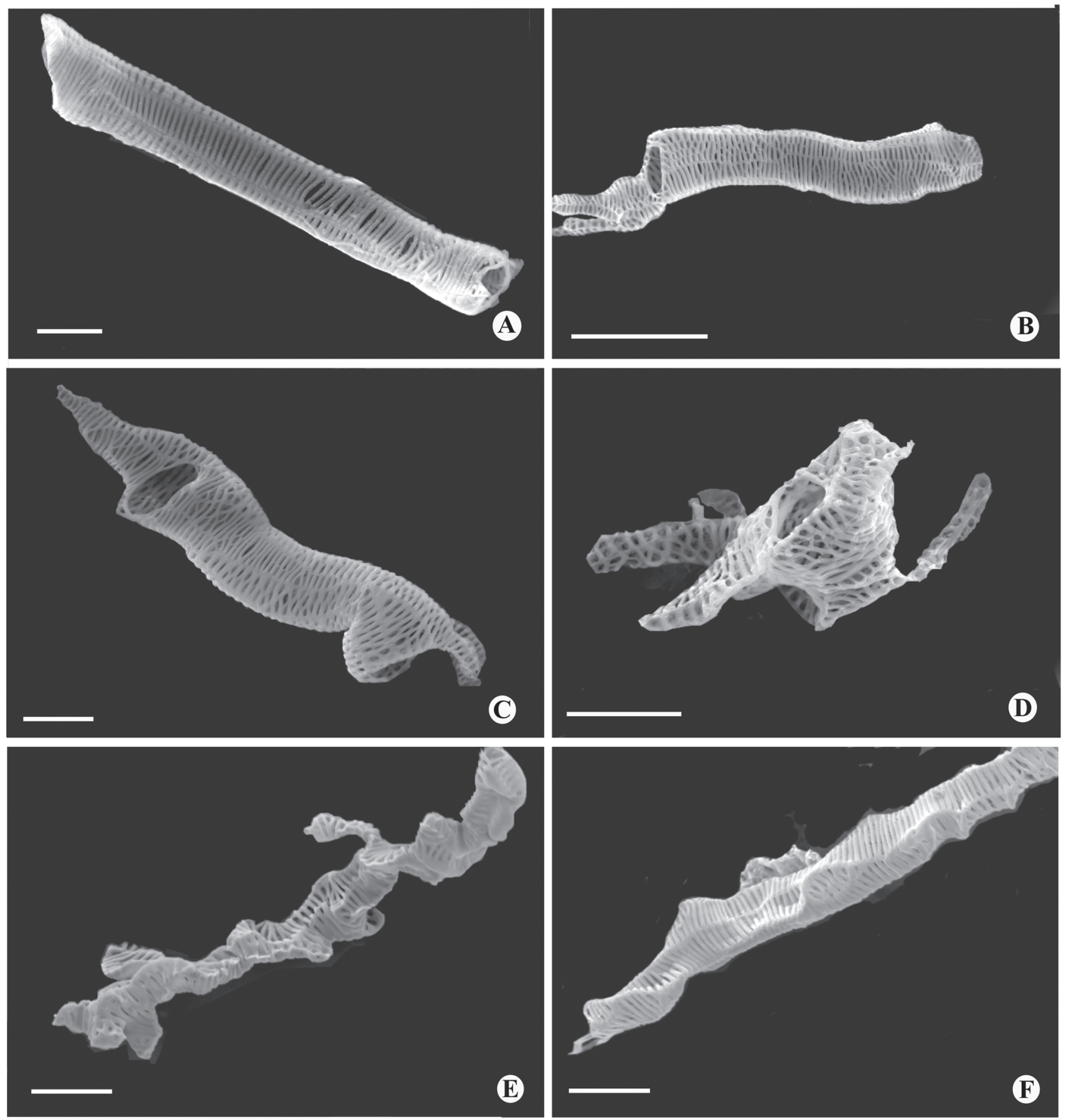

Figure 8. Tracheary elements of the stem in Cyperaceae species. A-B. Vessel elements in primary growth. A. Cyperus odoratus L. B. Fuirena umbellata Rottb. C-D. Vessel elements in secondary growth. C. Bulbostylis paradoxa Ness. D. Fuirena umbellata Rottb. E-F. Tracheids arise from secondary growth in Hypolytrum schraderianum Ness. Scale bars: A $=20 \mu \mathrm{m} ; \mathrm{B}=50 \mu \mathrm{m} ; \mathrm{C}-\mathrm{F}=20 \mu \mathrm{m}$. 
Corms are perennial, contracted, juicy stems, surrounded by dried scales or cataphylls (Bell 1991) which give rise to new life cycles through the sprouting of an apical bud; this occurs in C. esculentus and C. rotundus. Therefore, reports by Wills \& Briscoe (1970), Wills et al. (1980) e Wills (1987) about bulb are not correct.

The axillary bud in the rhizomes of Cyperus odoratus, Fuirena umbellata, Hypolytrum schraderianum and Bulbostylis paradoxa produce new sympodial units (or propagulum) which develop together with the mother plant, and when detached due to various circumstances, they constitute a vegetative reproduction unit. Sexual reproduction occurs when the vegetative meristem of each sympodial unit transforms itself into a flower meristem and develops the reproductive shoot, i.e. the scape and the flowers. This pattern of development is common in monocotyledons (Santos \& Silva 1997; Simão \& Scatena 2001; Alonso \& Moraes-Dallaqua 2004).

Authors like Cutter (1971) admit that the lengthening of the stem is carried out by activity in the subapical region or, in some cases, by the intercalary meristem which is located at the base of the younger internodes. This meristem has only been seen in the rhizome of Fuirena umbellata, which transforms into rib form, as in Eleocharis acuta (Evans 1965) and Cyperus alternitifolius (Fisher 1970). However, Estelita \& Rodrigues (2007) found intercalary meristem only in the scape. In Fig. 2 D-E (Fuirena umbellata) the transformation of vegetative into reproductive meristem can be admitted.

The primary thickening meristem (PTM) in Cyperaceae was recorded in Scirpus and Fimbristylis by Rudall (1991). Gifford \& Bayer (1995) also mention it in Cyperus esculentus and Rodrigues \& Estelita (2002) in C. giganteus. In this work it is present in all species.

The term PTM has been used for some time by several authors (Stevenson 1980; Rudall 1991). However, Zimmemann \& Tomlinson $(1968 ; 1969 ; 1970 ; 1972 ; 1974)$ refer to it as a "merismetic cap". Regarding its function, the PTM is involved in primary thickening of the stem and formation of adventitious roots and associated vascular system (Cheadle 1937; Krauss 1948; DeMason 1979a; b, 1980; 1983; Stevenson \& Fisher 1980; DeMason \& Wilson 1984; Rudall 1991; Gifford \& Bayer 1995; Rodrigues \& Estelita 2002). Meanwhile, Menezes et al. (2005) admit that PTM is the meristematic endodermis and the pericycle, therefore they do not use the term.

For DeMason (1979a; b) the function of PTM varies with growth habit. In small monocotyledons, PTM produces adventitious roots and an associated vascular system, while in monocotyledons, such as palms, which do not have a continuous vascular connection throughout the length of the stem, PTM is only responsible for primary thickening. In the species analyzed, PTM is responsible for primary thickening and the production of adventitious roots, as is also observed in Cyperus esculentus (Gifford \& Bayer 1995) and C. giganteus (Rodrigues \& Estelita 2002).
Within the species studied, PTM presents a variation in activity. In Cyperus odoratus, Hypolytrum schraderianum, Fuirena umbellata and Bulbostylis paradoxa which have thickened rhizomes, PTM produces parenchyma to the outside and vascular bundles to the inside. In C. rotundus and C. esculentus, which have slender rhizomes and stolons, PTM produces relatively less parenchyma to the outside and practically does not form vascular bundles to the inside. This activity variation may be related to the consistency of these organs. In the corms, PTM has high activity to the outside and little to the inside. The rhizomes of $F$. umbellata, C. odoratus, $H$. schraderianum and the corms of $C$. rotundus and $C$. esculentus are tuberous organs which have the function of storage, as well as reproduction.

The "neck" region of the rhizome of Hypolytrum schraderianum is also found in bamboo rhizomes, according to McClure (1993). This author emphasises that the "neck" seems less specialised due to the fact that its internal structure is simpler. In $H$. schraderianum no secondary growth occurs, which corroborates with the author's information. This situation should facilitate vegetative reproduction because if the neck region is less rigid, abscission, and consequently dispersal of that propagation unit, is easier. Also in the neck, a higher concentration of idioblasts with phenolic compounds is observed. It probably protects the organ, particularly during abscission, since tannins reduce digestibility of plant tissues minimising the action of the herbivores and pathogens (Howe \& Westley 1988).

Several authors make reference to the endodermis in rhizomes (Evans 1965; Wills \& Briscol 1970; Wills et al. 1980; Rodrigues \& Estelita 2002; Alonso \& Moraes-Dallaqua 2004; Menezes et al. 2005); some refer only to the endodermoid layer (Plowman 1906; Kukkonen 1967; Metcalfe 1971; Rudall 1984) because the Casparian strip was not observed. However, in the species studied, the endodermis is recognized by the arrangement of the suberin and thickening of the cell walls (Van Fleet 1961).

The cortex in Cyperaceae is generally divided into internal and external. The latter is characterized by several subepidermis layers, has its origin in the ground meristem, and is considered to be similar to hypoderm, a layer which occurs up to the leaves in this group, as can be seen in the studies of Williams (1947) and Metcalfe (1971). The internal cortex normally presents wide intercellular spaces comprising an aerenchyma, as observed mainly in the rhizomes of Cyperus rotundus and C. esculentus. DeMason (1979a; 1980) demonstrates, using histochemistry markers, that in Allium cepa the internal cortex is derived from PTM. This activity was questioned by Zimmermann \& Tomlinson $(1967 ; 1968)$. In the present study, it is observed that PTM forms the internal cortex (of which the innermost layer is the endodermis), the pericycle (which differentiates the vascular bundles) and the adventitious roots, as in $C$. giganteus, according to Rodrigues \& Estelita (2002). 
DeMason (1984) defines secondary growth as an increase in thickness of the stem, as a result of cell divisions which occur after the primary tissues mature. In monocotyledons, secondary growth is the result of the installation and activity of the secondary thickening meristem (STM), which is mentioned mainly for woody and shrubby species (Rudall $1991 ; 1995)$. Secondary growth in herbaceous species is less frequent (Tomlinson 1965).

Rudall (1995) refers to PTM and STM as "persistent pericyclic meristems". In the same work, the author comments that in some taxa such as Agave, Cordyline and Dracaena, the presence of STM is undisputed, but in others, it may be that PTM extends for several internodes from the top. Examples of transitional forms include Orthrosanthus chimboracensis (Rudall 1994) in which PTM continues for a great distance from the top, forming a hard vascular pericyclic plexus, which is probably homologous with secondary vascular tissue of other Iridaceae (Rudall 1995). In H. schraderianum, C. odoratus, B. paradoxa and $F$. umbellata there is no doubt as to the presence of STM because a change in activity is observed, whereby instead of vascular bundles being produced, a single vascular system is produced; this is supported by the fact that only tracheids continue to be formed in Hypolytrum schraderianum, similar to what Cheadle (1937) observed in the secondary growth of several monocotyledons, including Dracaena and Cordyline. Also Diggle \& DeMason (1983a) refer to the tracheids of secondary growth of Yucca whipplei. It is also emphasized that in secondary growth, the vessel elements are always shorter than the primary ones, as observed in the species analyzed.

The presence of branched tracheal members in the secondary xylem of various monocotyledons was mentioned by Cheadle (1937) while Diggle \& DeMason (1983a) also noticed branched tracheal members in Yucca whipplei. Branched members were also observed in the species studied here, and were discussed by Rodrigues \& Estelita (2002).

The PTM is considerably active in $H$. schraderianum, C. odoratus, F. umbellata and B. paradoxa, acting in both directions. It has restricted activity in $C$. rotundus and in the stems of $C$. esculentus, acting mainly to the outside, which has also been observed by Gifford \& Bayer (1995) in the latter species. Tomlinson \& Zimmenmann (1969) and Rudall (1991) admit that PTM should be plesiomorphic in monocotyledons, when compared with dicotyledons, and it tends to evolve between the various forms of contracted stems. Based on the above, C. esculentus and C. rotundus can be considered as more specialised stems than the previous species, since low PTM activity can indicate its possible elimination in the process of evolution. This possibility is supported by the occurrence of secondary growth in $H$. schraderianum, C. odoratus, F. umbellata and B. paradoxa, which may represent a plesiomorphic condition in relation to C. esculentus and C. rotundus.
According to Holttum (1955) and Tomlinson (1995), evolution in growth habit in monocotyledons originates from rhizomatous plants with branches in the basal nodes and cluster habit. It was followed by the sympodial rhizomes, which in turn developed the carneous rhizomes (adapted to dry conditions) and eventually by corms and bulbs.

The results give accurate analysis about the kind of stems in Cyperaceae and also enable an association between the presence and activity of PTM and STM and the evolutionary sequence referred to by the authors above. This is because they range from carneous rhizomes (with considerable activity in PTM and STM) to corms, without STM and with little activity of PTM.

\section{Acknowledgements}

We thank "Fundação de Amparo a Pesquisa do Estado de São Paulo" - FAPESP (Proc. 00/01040-6) for financial support.

\section{References}

Alonso, A.A. \& Moraes-Dallaqua, M. 2004. Morfoanatomia do sistema caulinar de Canna edulis Kerr-Gawler (Canaceae). Revista Brasileira de Botânica 27: 229-239.

Bell, A.D. 1991. Plant form. A illustration guide to flowering plant morphology. Oxford, University Press.

Bell, A.D. \& Tomlinson P.B. 1980. Adaptative architecture in rhizomatous plants. Botanical Journal of the Linnean Society 80: $125-160$.

Bendixen, L.E. 1973. Anatomy and sprouting of yellow nutsedge tubers. Weed Science 21: 501-503.

Bozzola, J. \& Russel, L. 1991: Electron microscopy, principles and techiniques for biologist. Boston, Jones and Barlett Publishers.

Bukatsch, F. 1972. Bemerkungen zur Doppelfärbung AstrablaoSafranin. Microkosmos 61: 255.

Cheadle, V.I. 1937. Secondary growth by means of a thickening ring in certain monocotyledons. Botanical Gazette 98: 535-555.

Cutter, E.G. 1971. Plant anatomy: Experiment and interpretation. Part II. Great Britain, Edward Arnold.

DeMason, D.A. 1979a. Histochemistry of the primary thickening meristem in the vegetative stem of Allium cepa L. American Journal of Botany 66: 347-350.

DeMason, D.A. 1979b. Function and development of primary thickening meristem in the monocotyledon, Allium cepa L. The Botanical Gazette 140: 51-66.

DeMason, D.A. 1980. Localization of cell division activity in the primary thickening meristem in Allium cepa L. American Journal of Botany 67: 393-399.

DeMason, D.A. 1983. The primary thickening meristem: Definition and function in monocotyledons. American Journal of Botany 70: 955-962.

DeMason, D.A. 1984. Stem thickening in monocotyledons. In: M. Iqbal (ed.). Growth patterns in vascular plants. Oregon, Portland.

DeMason, D.A. \& Wilson, M.A. 1984. The continuity of primary and secondary growth in Cordyline terminalis (Agavaceae). Canadian Journal of Botany 63: 1907-1913.

Diggle, P.K. \& DeMason, D.A. 1983a. The relationship between the primary thickening meristem and the secondary thickening meristem in Yucca whipplei Torr. I. Histology of the mature vegetative stem. American Journal of Botany 70: 1195-1204.

Diggle, P.K. \& DeMason, D.A. 1983b. The relationship between the primary thickening meristem and the secondary thickening meristem in Yucca whipplei Torr. II. Ontogenetic relationship within the vegetative stem. American Journal of Botany 70: 1205-1216. 
Eiten, L.T. 1969. The vegetative anatomy of Elocharis interestincta (Vahl) Roem. \& Schult. Arquivos de Botânica do Estado de São Paulo 4: 187-228.

Esau, K. 1967. Plant anatomy. New York, John Wiley \& Sons.

Estelita-Teixeira, M.E. 1982. Shoot anatomy of three bulbous species of Oxalis. Annals of Botany 49: 805-813.

Evans, P.S. 1965. Intercalary growth in the aerial shoot of Eleocharis acuta $\mathrm{R}$. Br. Prodr. I. Structure of the growing zone. Annals of Botany 29: 205-217.

Fisher, J.B. 1970. Development of the intercalary meristem of Cyperus alternifolius. American Journal of Botany 57: 691-703.

Font Quer, P. 1979. Dicionario de Botánica. Barcelona, Labor.

Franklin, G.L. 1945. Preparation of thin sections of synthetic resin and wood-resin composites, and a new marcerating method for wood. Nature 3924: 51.

Gifford, E.M. \& Bayer, D.E. 1995. Developmental anatomy of Cyperus esculentus (Yellow nutsedge). International Journal of Plant Science 156: 622-629.

Gifford, E.M. \& Tepper, H.B. 1962. Ontogenetic and histochemical changes in the vegetative shoot tip of Chenopodium album. American Journal of Botany 49: 902-911.

Holm, T.H. 1929. The application of the term "rhizome." Rhodora 30: 6-17.

Holttum, R.E. 1955. Growth-habits of monocotyledons - variations on the theme. Phytomorphology 5: 399-413.

Howe, H.F. \& Westley, L.C. 1988. Ecological relationships of plants and animals. New York, Oxford Universty Press.

Jensen, W.A. 1962. Botanical histochemistry. New York, H.H Freeman and Co.

Johansen, D.A. 1940. Plant microtechnique. New York, McGrawHill Book Co.

Krauss, B.H. 1948. Anatomy of the vegetative organs of the pineapple, Ananas comosus (L.) Merr. I. Introduction, organography the stem and the lateral branch or axillary buds. Botanical Gazette 110: $159-217$.

Kukkonen, I. 1967. Vegetative anatomy of Uncinia (Cyperaceae). Annals of Botany 31: 523-544.

Luceño, M. \& Alves, M.V. 1997. Clave de los géneros de ciperáceas de Brasil y novedades taxonómicas y corológicas en la familia. Candollea 52: 185-197.

Martin, B.F. \& Tuucker, S.C. 1985. Developmental studies in Smilax (Liliaceae). I. Organography and the shoot apex. American Journal of Botany 72: 66-74.

Martins, A.R. \& Appezzato-da-Glória, B. 2006. Morfoanatomia dos órgãos vegetativos de Smilax polyantha Griseb. (Smilacaceae). Revista Brasileira de Botânica 29: 555-567.

McClure, F. 1993. The Bamboo. Boston, Harvard University.

Menezes, N.L.; Silva, D.C; Arruda, R.C.O.; Melo-de-Pinna, G.F.; Cardoso, V.A.; Castro, N.M.; Scatena, V.L. \& Scremin-Dias, E. 2005. Meristematic activity of the endodermis and the pericycle in the primary tickening in monocotyledons. Considerations on the "PTM". Anais da Academia Brasileira de Ciências 77: 259-274.

Metcalfe, C.R. 1971. Anatomy of the monocotyledons. Cyperaceae. London, Oxford University Press.

Plowman, A.B. 1906. The Comparative Anatomy and Phylogeny of the Cyperaceae. Annals of Botany 20: 1-33.

Rodrigues, A.C. \& Estelita, M.E.M. 2002. Primary and secondary develoment of Cyperus giganteus Vahl rhizome (Cyperaceae). Revista Brasileira de Botânica 25: 251-258.
Rudall, P. 1984. Taxonomic and evolutionary implications of rhizome structure and secondary thickening in Iridaceae. The Botanical Gazette 145: 524-534.

Rudall, P. 1991. Lateral meristem and stem thickening growth in monocotyledons. The Botanical Review 57: 150-163.

Rudall, P. 1995. New records of secondary thickening in monocotyledons. Iawa Journal 16: 261-268.

Santos, G.O. \& Silva, E.A.M. 1997. Crescimento e desenvolvimento do rizoma de gengibre (Zingiber officinale Rosc.). Arquivos de Biologia e Tecnologia 40: 651-656.

Simão, D.G. \& Scatena, V.L. 2001. Morphology and anatomy in Heliconia angusta Vell. and $H$. velloziana L. Emygd. (Zingiberalis: Heliconiaceae) from the Atlantic forest of southeastern Brazil. Revista Brasileira de Botânica 24: 415-424.

Stevenson, D.W. 1980. Radial Growth in Beaucarne recurvata. American Journal of Botany 67: 476-489.

Stevenson, D.W. \& Fisher, J.B. 1980. The developmental relationship between primary and secondary thickening growth in Cordyline (Agavaceae). The Botanical Gazette 141: 264-268.

Tomlinson, P.B. 1965. Notes on the anatomy of Aphyllanthes (Liliaceae) and compararison with Eriocaulaceae. Journal of the Linnean Society 59: 163-173.

Tomlinson, P.B. 1995. Non-homology of vascular organization in monocotyledons and dicotiledons. In P.J. Rudall; P.J. Cribb; D.F. Cutler \& C.J. Humphries (eds.). Monocotyledons: Systematics and Evolution. Londres, Kew Royal Botanical Gardens.

Tomlinson, P.B. \& Zimmermann, M.H. 1969. Vascular anatomy of monocotyledons with secondary growth - an introduction. Journal of the Arnold Arboretum 50: 159-179.

Van Fleet, D.S. 1961. Histochemistry and function of the endodermis. Botanical Review 27: 165-221.

Williams, B.C. 1947. The structure of the meristematic root tip and origin of the primary tissues in the roots of vascular plants. American Journal of Botany 34: 455-462.

Wills, G.D. 1987. Description of purple and yellow nutsedge (Cyperus rotundus and C. esculentus). Weed Technology 1: 2-9.

Wills, G.D. \& Briscoe, G.A. 1970. Anatomy of purple nutsedge. Weed Science 18: 631-635.

Wills, G.D.; Hoagland, R.E. \& Paul, R.N. 1980. Anatomy of yellow nutsedge (Cyperus esculentus). Weed Science 28: 432-437.

Zimmermann, M.H. \& Tomlinson, P.B. 1967. Anatomy of the palm Rhapis excelsa. IV. Vascular development in apex of vegetative aerial axis and rhizome. Journal of the Arnold Arboretum 48: $122-142$.

Zimmermann, M.H. \& Tomlinson, P.B. 1968. Vascular construction and development in the aerial stem of Prionium (Juncaceaae). American Journal of Botany 55: 1100-1109.

Zimmermann, M.H. \& Tomlinson, P.B. 1969. The vascular system in the axis of Dracaena fragans (Agavaceae). I. Distribution and development of primary strands. Journal of the Arnold Arboretum 50: 370-383.

Zimmermann, M.H. \& Tomlinson, P.B. 1970. The vascular system in the axis of Dracaena fragans (Agavaceae). II. Distribution and development of secondary vascular tissue. Journal of the Arnold Arboretum 51: 478-491.

Zimmermann, M.H. \& Tomlinson, P.B. 1972. The vascular anatomy of monocotyledons stems. Botanical Gazette 133: 141-155.

Zimmermann, M.H. \& Tomlinson, P.B. 1974. Vascular patterns in palm stems: Variations of the Rhapis principle. Journal of the Arnold Arboretum 55: 402-424. 